\title{
Whose Bad Guys Are Terrorists?
}

\author{
Rainer Bauböck
}

Peter Schuck, Christian Joppke and Kay Hailbronner have provided strong arguments why liberal democracies should have the power to strip terrorist suspects of their citizenship. As good lawyers, Schuck and Hailbronner add that such power must be exercised with restraint and hedged in by the rule of law.

Everybody in this debate agrees that terrorists ought to be punished. Most would also agree that liberal states need exceptional powers in order to prevent terrorism and that this justifies some constraints on freedom of speech and association, for example by making incitement to terrorist violence or joining a terrorist organisation punishable crimes.

Terrorists commit particularly evil crimes. Yet denationalisation does not look like punishment for these crimes. First, it is normally based on executive order rather than court judgment. Second, it does not meet the standard purposes for criminal punishment. It cannot be justified as retribution, since it is not proportionate to the monstrosity of the crime. It does not promote rehabilitation, since the effect is to remove the criminal from the jurisdiction. And it is not effective in deterring or preventing terrorist crimes, sinceas Vesco Paskalev has argued - global jihadists hardly care about losing citizenship status in a Western democracy that they detest.

Hailbronner points out that terrorists care about losing their right to travel, but restricting their freedom to move can also be achieved by other means, e.g. by invalidating their passports without denationalising them. Banishing jihadists to exactly those states where they want to go anyway to commit their atrocities can hardly count as an effective strategy against global terrorism. As a political scientist I suspect that governments have other motives apart from policy effectiveness when they seek denationalisation powers. They do not only want to do something against terrorism, they also want to be seen by voters as doing something. Stripping terrorist suspects of their citizenship is a strongly visible policy and for that reason possibly also a strongly symbolic one, as suggested by Peter Spiro. 
This is not yet a conclusive refutation, since on some views it is exactly the symbolic nature of the sanction that justifies the denationalisation of terrorists. This argument starts from the assertion that liberal democracies are value-based political communities. Their basic values include freedom of conscience and religious practice, of speech and association and democratic self-government. Since these states are liberal, they cannot force their citizens to share their basic values. These are instead enshrined in their constitutions and their political institutions are designed to protect these values. Terrorists do not merely reject liberal values, they act to destroy the very institutions that protect these values. So why should liberal states not take away citizenship from those who attack the very foundations of liberal citizenship? Wouldn't this serve to defend these states' core values?

The answer is that the norms guiding the acquisition and loss of citizenship status have little to do with either the promotion or the defence of liberal values. In all states, including liberal ones, citizenship is acquired automatically at birth and normally retained over a whole life. Native citizens are never asked to show their commitment to liberal values as a condition for retaining their citizenship, nor are they stripped of their status when they commit crimes. Serious criminals are locked up in prison and thereby stripped of many citizenship rights, most importantly that of free movement. In some countries they also lose - and in my view much more questionably - voting rights. But they do not lose their citizenship status. Citizenship in our world has an extremely sticky quality. It does not have an expiry date, it can be passed on to subsequent generations and it can be carried abroad and increasingly also exercised from outside the state territory.

Yet many liberal states have introduced citizenship tests or naturalisation oaths in which immigrants are asked to affirm their commitment to the polity and its constitution. ${ }^{1}$ Doesn't this show that acquisition of citizenship status and therefore also its loss may depend on a commitment to liberal values? No, it doesn't. Leaving aside the tricky question whether such commitments can be tested by filling in a questionnaire or taking an oath, naturalisation integrates newcomers into a political community that is based on birthright membership and equal citizenship. No matter how they have been selected and how they have acquired their citizenship, all citizens have equal

\footnotetext{
See: Bauböck, R. \& Joppke, C. (eds.) (2010), 'How Liberal are Citizenship Tests?', Robert Schuman Centre for Advanced Studies-EUDO Citizenship Observatory Working Paper N. 2010/41. Florence: European University Institute, available at: http://cadmus.eui.eu/handle/1814/13956.
} 
membership status and those who have got it through naturalisation can retain it in the same way as if they had got it by birth.

This statement needs two minor qualifications. First, if citizenship has been acquired unlawfully, for example through concealing a criminal record, then it may be withdrawn. This reasoning cannot be applied to citizens who assert their commitment to a liberal constitution in a citizenship test or loyalty oath that they subsequently violate. Because liberal states cannot force ordinary citizens to support their core values, they also cannot claim that citizenship status has been acquired unlawfully if a naturalisation applicant was not sincere when swearing loyalty or was sincere and subsequently changed his views.

Second, the norm of equal treatment of native and naturalised citizens is not accepted by all liberal states - as we all know, the American President must be a native citizen. It is, however, enshrined in Art. 5 of the 1997 European Convention on Nationality and it is not difficult to see why unequal treatment of citizens based on their circumstances of birth is discriminatory and undermines the core value of equality. Faced with terrorism that is now no longer just imported but also home-grown, Western governments may anyhow be reluctant to limit the application of their denationalisation powers to naturalised immigrants.

There are two closely connected reasons why citizenship status is sticky and why it should not be taken away even for acts that attack the foundations of the polity. The first reason has to do with the function of nationality in the international state system. Citizenship is a mechanism for assigning responsibility for individuals to states. In its 1955 Nottebohm judgment the International Court of Justice asserted that citizenship should be based on a genuine connection in order to prevent states from abusively bestowing their citizenship on individuals residing abroad who want to escape a legal duty towards their host country. The same genuine link argument has been invoked by the European Parliament and Commission against Malta in January 2014 as an objection against the sale of EU citizenship to wealthy foreigners without a residence requirement. ${ }^{2}$ If states can abuse their powers to confer citizenship by naturalising foreigners who lack a genuine

2 See the press release of EU Justice Commissioner Vivian Reding 'Citizenship must not be for sale' (15 January 2014), available at http://europa.eu/rapid/ press-release_SPEECH-14-18_fr.htm, the 'European Parliament resolution of 16 January 2014 on EU Citizenship for Sale', available at http://www.europarl. europa.eu/sides/getDoc.do?pubRef=-//EP//TEXT+TA+P7-TA-2014$0038+0+\mathrm{DOC}+\mathrm{XML}+\mathrm{V} 0 / / \mathrm{EN}$ and Part I of this volume. 
connection, they can also do so by denationalising their citizens in order to shift responsibility for them to another state. This is exactly what happens when Western countries deprive terrorist suspects of their citizenship. As Audrey Macklin has already explained, the effects can be particularly perverse for dual citizens. Since deprivation does not make them stateless, each of the two states involved has an incentive to act first so that the other state becomes responsible.

International law can thus not provide a full answer to our question. We must also consider what depriving terrorist suspects does to the citizenship bond as an internal relation between an individual and a state. Joppke points out that Germany did not expatriate the left wing terrorists of the Red Army Faction. They wanted to transform the German state whereas the global jihadists de facto renounce their membership by affiliating themselves with an Islamic pseudo-state. But the RAF was certainly as effective in shaking the foundations of a liberal Rechtsstaat by triggering illiberal responses as was Al Qaeda when it fell the twin towers in New York - and much more so than IS, which primarily wants to scare Western powers out of Iraq and Syria. In any case, the question here is not whether Ulrike Meinhof and Andreas Baader had a moral claim to German citizenship that jihadist terrorist suspects do not have. The question is whether Western democracies can shed responsibility for their home-grown citizen terrorists and shoulder it upon other states. This is what the new denationalisation policies are about.

Imagine for a moment that after 1945 Germany or Austria had posthumously denationalised Adolf Hitler. Would this symbolic act have strengthened their post-war liberal orders by demonstrating their abhorrence of Hitler's destruction of their liberal constitutions and his genocidal elimination of Jews and Roma from the political community? The answer is clearly no, because Hitler's denationalisation would have entailed a denial of responsibility for his crimes and their consequences and would thus have achieved the very opposite of the intended defence of liberal values. Moreover, if either Germany or Austria had taken such a decision, it would have signalled that they merely wanted to pass on the buck to the other state. Recognising that Hitler was 'our bad guy' was therefore crucial for building a liberal democratic consensus in both countries and good relations with other states that were the victims of Nazi aggression.

Why should this be different today with the jihadist terrorists? Joppke's answer involves an attempt to distinguish domestic from global terrorists. This may be often difficult, since Hitler turned out to be a global terrorist too. But the crucial point is that citizenship is by its very nature a domestic relation between an individual and a state. By cutting the bond, states deny 
their responsibility, including that towards the rest of the world upon whom they inflict the terrorist threat.

If denationalisation were a necessary and effective tool to prevent terrorism, it might be justifiable on such utilitarian grounds. But as a symbolic defence of the liberal values that terrorists attack it is entirely unconvincing.

Open Access This chapter is licensed under the terms of the Creative Commons Attribution 4.0 International License (http://creativecommons.org/licenses/by/4.0/), which permits use, sharing, adaptation, distribution and reproduction in any medium or format, as long as you give appropriate credit to the original author(s) and the source, provide a link to the Creative Commons license and indicate if changes were made.

The images or other third party material in this chapter are included in the chapter's Creative Commons license, unless indicated otherwise in a credit line to the material. If material is not included in the chapter's Creative Commons license and your intended use is not permitted by statutory regulation or exceeds the permitted use, you will need to obtain permission directly from the copyright holder.

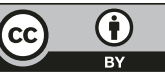

